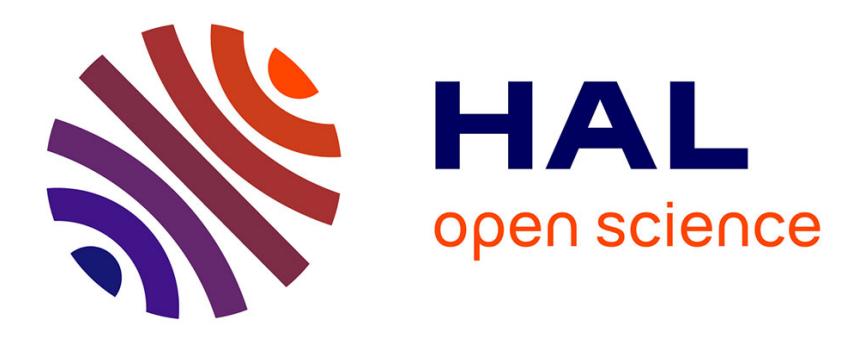

\title{
The implicit in Sarasvathy's work: Highlighting a communication theory in entrepreneurship
}

Christophe Schmitt

\section{To cite this version:}

Christophe Schmitt. The implicit in Sarasvathy's work: Highlighting a communication theory in entrepreneurship. Projectics / Proyéctica / Projectique, 2021, 1 (28), pp.95-111. 10.3917/proj.028.0095 . hal-03169153

\section{HAL Id: hal-03169153 \\ https://hal.univ-lorraine.fr/hal-03169153}

Submitted on 16 Mar 2021

HAL is a multi-disciplinary open access archive for the deposit and dissemination of scientific research documents, whether they are published or not. The documents may come from teaching and research institutions in France or abroad, or from public or private research centers.
L'archive ouverte pluridisciplinaire HAL, est destinée au dépôt et à la diffusion de documents scientifiques de niveau recherche, publiés ou non, émanant des établissements d'enseignement et de recherche français ou étrangers, des laboratoires publics ou privés. 


\section{THE IMPLICIT IN SARASVATHY'S WORK: HIGHLIGHTING A COMMUNICATION THEORY IN ENTREPRENEURSHIP}

\section{Christophe Schmitt}

Professeur et Titulaire de la Chaire Entreprendre, IAE de Metz, Université de Lorraine

\section{ABSTRACT}

We commonly consider the contribution of the effectuation developed by Sarasvathy as an alternative perspective to the causation one. In this paper, the author defends the idea that, even if these two logics were built on different pillars, the causation and the effectuation are eventually two sides of a coin. To understand the structuring of these two logics, the author mobilize Palo Alto's theory of communication, which is extended in order to include entrepreneurship in another paradigm: the paradigm of entrepreneurial action. The paper ends with a discussion of the interest of the latter within entrepreneurship research.

Keywords: effectuation, theory of communication, entrepreneur, artifacts, network actors, causation, effectuation, decision paradigm, entrepreneurial action paradigm

\section{RÉSUMÉ}

Il est commun, en entrepreneuriat, de considérer que l'apport de la logique effecuale développée à partir des travaux de Sarasvathy se situe avant tout dans une perspective d'alternative à la logique causale. Dans cet article, nous avançons l'idée selon laquelle, même si ces deux logiques se sont construites sur des piliers différents, la logique de causation et la logique effectuale ne sont finalement que les deux faces d'une même pièce. Pour comprendre la structuration de ces deux logiques, nous mobilisons la théorie de la communication de Palo Alto afin d'inscrire l'entrepreneuriat dans un autre paradigm : le paradigme de l'agir 
entrepreneurial. L'article se termine par une discussion portant sur l'intérêt de ce nouveau paradigme dans le cadre de la recherche en entrepreneuriat.

Mots clés : effectuation, théorie de la communication, entrepreneur, artefacts, acteurs de l'écosystème, causation, paradigme de la décision, paradigme de l'agir entrepreneurial

Une version en langue française est disponible auprès de l'auteur.

\section{INTRODUCTION}

When reading Sarasvathy's work, it is necessary to note the importance of two main notions (cf. annex): intersubjectivity (Venkataraman, Sarasvathy, Dew, Forster, 2012 and Towsend, Hunt, McMullen, Sarasvathy, 2018) and artifacts (Sarasvathy, 2003; Sarasvathy, Dew, 2004 and 2005; Sarasvathy, Dew, Read, Wiltbank, 2008). These two notions reflect the thoughts of Sarasvathy on entrepreneurship. However, they are rarely addressed concurrently by Sarasvathy in studies dealing with effectuation in entrepreneurship. Yet, we believe that there are interesting research prospects at this level. In this article, we make the assumption that these two notions, pillars of Sarasvathy's thoughts, refer back, without explicitly pointing it out, to the idea that entrepreneurship falls above all within a theory of communication, based on the interactions between individuals, according to the Palo Alto School (Watzlawick et al., 1967). Linking intersubjectivity with the notion of artifact makes it possible to consider entrepreneurship from a triad perspective: entrepreneur, artifacts and network actors (Schmitt, 2018 et 2020). This innovative idea in entrepreneurship research opens up new perspectives in terms of research avenues. Through such consideration, we have decided to focus on the thinking of Sarasvathy who, at the turn of the 2000s, proposed a conception of entrepreneurship which breaks with the traditional approach. It will therefore not be a question of covering all works relating to effectuation. This choice is justified by the fact of being able to propose another way to develop new insights in entrepreneurship, by focusing on the contribution of a certain author who has become a reference in the field. By doing so, we are in line with Steyaert's work (2007), who brings unique insights at Sarasvathy's work on effectuation. In fact, the position itself of an author - whose research is well recognized and praised - regarding the subject by which he considerably supports his theory provides both substance and consistency to such position, thereby seizing it as the highlights of research. In this perspective, we relied on 10 articles written by Sarasvathy between 2001 and 2018 referring to the debate on effectuation (cf. annex). We can see a progress in her thinking around 2010, a progress highlighting above all the links between the entrepreneur and the artifacts that prevail, 
as a result of which the relations between the entrepreneur and the network actors emerge (intersubjectivity), put forward without having a direct relationship between intersubjectivity and artifacts ${ }^{1}$. We will also show that there is still a decisive step that has not been taken yet by Sarasvathy to consider entrepreneurship as a theory of communication, based on the interactions between individuals, by connecting the two pillars of effectuation, i.e. intersubjectivity and artifacts.

In this vein, the theory of communication is introduced to us as the natural extension of the thoughts presented by Sarasvathy on effectuation through the notions of intersubjectivity and artifacts. The theory of communication refers to the fact of sending out a message intended as an artifact between a transmitter and a recipient, obviously at a minimum. It is about going further than the intersubjectivity proposed by Sarasvathy. We propose to show that the entrepreneur, the artifacts and the network actors represent a "whole", an entirety that should be perceived as a triad. This triad can be apprehended as the smallest constitutive unit in some pragmatic research perspectives on entrepreneurship. It should be likewise approached as an indivisible entity.

Since the elements of the triad interact with each other, we, as researchers, are studying how people interact with each other. In this perspective, our contribution provides an extension of the interactionist approaches (Johannisson 1995; Steyaert 2007; Steyaert and Landström 2011; Moroz and Hindle 2012), which clearly highlight the importance of the entrepreneurial process. This reinforces the pragmatic posture proposed by Sarasvathy in her research on entrepreneurship, especially through effectuation. Previous studies have already proposed to go beyond the framework of effectuation, namely those of Steayart (2007) which aim to enrich the thinking environment by adopting the interactionist dimension through the Actor-Network Theory² (Latour 2005; Gherardi and Nicolini 2005). On our side, we suggest enriching the debate on effectuation by proposing a phenomenological thinking environment substantiated by the theory of communication. We have interpreted Sarasvathy's work in light of key notions relating to effectuation to see how they are being used in such work.

\section{STATEMENT OF THE MOTIVES}

Placing Sarasvathy's work within a theory of communication paves the way for a change of perspective in entrepreneurial research, particularly concerning the interactions between the components of the triad: the entrepreneur,

1. The article by Venkataraman, S., Sarasvathy, S., Dew, N., and Forster, W. 2012 is that which reveals a strong coexistence of the notions of artefact and intersubjectivity without proposing a specific research framework.

2. The difference between the actor-network theory and the theory of communication lies mainly in the role assigned to artifacts. In the theory of communication, even if we acknowledge the importance of artifacts, they are still not considered as full-fledged actors as in the Actor-Network Theory, but as intermediation objects between actors. 
the artifacts and the network actors. The subject of this article is not neutral. It aims to propose a method to go beyond the duality between causation and effectuation (Sarasvathy, 2001; Fischer, 2012; Reymen and al., 2015; Smolka and al., 2016) in which entrepreneurship research was incorporated due to the monad on the one hand, relating to the causalistic dimension, and to the dyad on the other, relating to the effectual dimension, while proposing a triadic perspective. In other words, the ideas developed herein aim to show how we could get out of:

- the monad relating to the methodological individualism of the causal approach, where entrepreneurship is interpreted in the light of individuals viewed in isolation;

- the two dyads highlighted in Sarasvathy's effectual approach: 1) the links between the entrepreneur and the artifacts $^{3}$ and 2) intersubjectivity, i.e. the links between the entrepreneur and the network actors ${ }^{4}$;

in order to focus on a theory of communication (triad) which links entrepreneur, artifacts and network actors. The importance of the triad lies particularly in understanding the interactions between these three elements, their rules, their frequencies, etc. as a construction process of scientific knowledge. The results of a theory of communication in entrepreneurship should be hence gathered as a set of simple rules, a grammar valid for the countless variants of the entrepreneurial situations encountered (Welter, 2010; Dew and others 2015; Schmitt and Husson, 2017) in a paradigm: the entrepreneurial action paradigm (2015 a et b). The paradigm of entrepreneurial action then becomes an alternative to the decision paradigm through which causation and effectuation are considered dual (Watson, 2013, Schmitt et Julien, 2020).

Figure 1 : From decision paradigm to entrepreneurial action's one

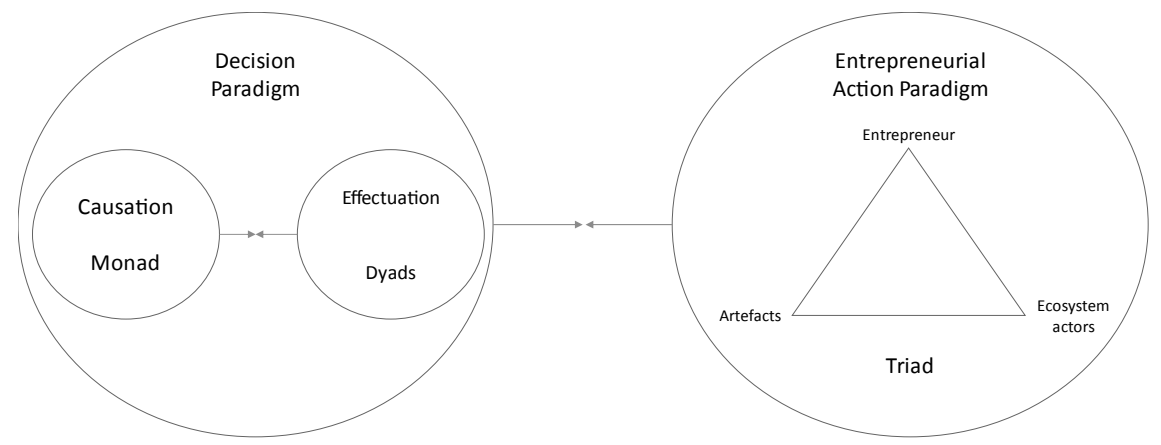

The first part of this article stresses the importance of the triad as an analytical grid for entrepreneurship. It discusses the limits of entrepreneurship approaches which focus either on a monad according to the causation perspective, or on a dyad according to the effectuation perspective, and introduces the triad as well as its role in the paradigm of the entrepreneurial act. In the second part, we will show first that causation and effectuation are 
two sides of the same coin that fit into the paradigm of decision. By aiming to approach entrepreneurship based on the theory of communication, we secondly propose to consider the entrepreneurial action paradigm as one which allows us to go beyond that of causation and effectuation. In the third part, we will discuss what we mean by the entrepreneurial action paradigm. We will mainly examine the link between the triad and entrepreneurial action through the notion of the entrepreneurial situation. In the fourth and last part, we will discuss the interest of the theory of communication and the entrepreneurial action paradigm to complement effectuation and pave the way for new avenues for entrepreneurship research, particularly through the notion of intentionality stemming from phenomenology (Husserl, 1913/2017).

\section{THE TRIAD AS AN ANALYTICAL GRID FOR ENTREPRENEURSHIP}

In the first part, we assume that entrepreneurship can be viewed as a communication logic referring to the interaction between the transmitter, the sign and the recipient, i.e. between the entrepreneur, the artifacts and the network actors. The elements of this triad are undoubtedly present in the work of Sarasvathy, but in a scattered manner, even implicitly throughout the demonstrations dealing with the intersubjective dimension of entrepreneurship on the one hand (Venkataraman, Sarasvathy, Dew, and Forster, 2012), and on the other hand, with the artificial dimension of entrepreneurship (Sarasvathy, 2003). The links between the elements of the triad are thus implicit in the discourse of Sarasvathy without, however, being considered as such in her thinking. This is why it is necessary to describe this triad and its role as the smallest constitutive and indivisible unit in any entrepreneurship research. The interactions between these three elements refers to what can be called an entrepreneurial situation (Schmitt and Husson, 2017).

The inherent organization of the elements representing an entrepreneurial situation (people and artifacts) implies reciprocal relationships among all the elements, which means that they communicate with each other (Watzlawick, 1967). This idea of a triad makes it possible to complete the dyads and to go further than the intersubjectivity and artificiality proposed by Sarasvathy in her works. In fact, intersubjectivity is limited to interactions between two people without taking artifacts into consideration. On the other hand, the contribution of artifacts is often viewed without direct connection to the entrepreneur or to the ecosystem actors. We propose to highlight the importance of linking intersubjectivity and artifacts. For this very reason, we are committed to the theory of communication. The fact that the researcher examines the communicative behavior of the entrepreneurial situation's elements, that is to say a determined use of artifacts and effects induced by them to people who are within the situation, entrepreneur and network actors, falls within the field of the theory of communication (study of situated signs). However, it is worth noting that research dealing with the interactions 
of this triad is still limited in entrepreneurship (Johannisson 1995; Steyaert 2007; Steyaert and Landström 2011; Moroz and Hindle 2012). There is nonetheless a research potential which still seems to be little explored. In general, entrepreneurship research has been established around a monad, the transmitter, i.e. the entrepreneur, in a causal approach based on methodological individualism, or around a dyad in an effectual approach based on intersubjectivity, through the links between transmitter and recipient or the links between entrepreneur and artifacts. Despite the proven interest of Sarasvathy's works on effectuation which certainly set us free from the causal approach, the fact remains that they enclose us into a multifaceted duality between causation/effectuation, monad/dyad, methodological individualism/intersubjectivity (Schmitt, 2020). The use of a triad, through the theory of communication, represents a scientific opportunity which makes it possible to get out of the duality on which entrepreneurship research has been founded lately (Arend, Sarooghi and Burkemper, 2015). As a result, we believe that it is restricting to exclusively study the transmitter (the entrepreneurl, or the relationship between the transmitter and the recipient, without considering the artifacts which establish relationships with people in connection with the given situation. Pierce (1839-1914) had already shown that the artifact does not exist without connection with a certain transmitter and a certain recipient.

In fact, artifacts are built as much by the entrepreneur as by the network actors in a perspective of communication between them. The artifact is therefore a means of communication between the entrepreneur and the network actors. Better still, the artifact is a reflection of the relationship between the world of the entrepreneur and the network actors. In a phenomenological perspective of entrepreneurship (Berglund, 2007, Schmitt, 2015, 2018 and 2020), the artifact is the vector, whether conscious or unconscious, of the intentionality that carries it. From a methodological point of view, we notably focus on research that deals with communication between people and takes into account the artifacts produced in and through the communication that connects them. It seems appropriate, at least, to develop methodological protocols to examine the action when it is done and to be able to confront the representations of people involved in the action and, more generally, in the entrepreneurial situation. For instance, it is possible to study the commitment of the entrepreneur through the actions he implements, the artifacts he develops, the perception he has of his own commitment and the network actors. The collected data must therefore comply with the elements of the triad. 


\section{PARADIGMS OF ENTREPRENEURSHIP RESEARCH: FROM THE DECISION PARADIGM TO THE ENTREPRENEURIAL ACTION ONE}

Research studies conducted based on the monad perspective refer above all to the explanation of an object independent of its context rather than the understanding of interactions. They fit within the causal approach according to Sarasvathy (2001). This is typically the case for current research on entrepreneurial intention (Krueger and Carsud, 1993; Krueger, 2017), for example. They are studies which introduce explanatory models using hypotheses that will be validated or not by statistical surveys conducted on a given population. By focusing on the entrepreneur at the survey level, the point of view of the network actors is thus clearly neglected, as are the artifacts related to the entrepreneur and the network actors. In this perspective, entrepreneurship research solely focuses on explaining the purpose: the entrepreneurial intent.

In the dyad proposed by Sarasvathy through her works on effectuation, we move beyond the explanation around a decontextualized object of study to become more interested in the interactions of the entrepreneur with the network actors based on intersubjectivity, that of the entrepreneur with the artifacts. These ideas have particularly brought a new spirit in research dealing with business opportunity (Sarasvathy, Dew, 2004 and 2005, Venkataraman, Sarasvathy, Dew, and Forster, 2012; Towsend et al., 2014). In the debate made by Alvarez and Barney (2007), it is possible to consider the opportunity as a piece of data or a construct. This debate can be enlightened by using both the monad and the dyad. In a monadic approach based on causation, opportunity is primarily considered as pre-existing objective data in the entrepreneur's environment that the latter must "pick". In a dyadic approach based on effectuation, the business opportunity is represented as a construct of the entrepreneur in relation to the situation in which he is found. Therefore, the debate on business opportunities is above all a debate of posture, that is to say the way in which one considers conducting entrepreneurship research.

These two postures of research clash. On the one hand, the research posture on the object of study identifies the monad as the smallest constitutive unit in the sense that Leibniz understands it. This monadic approach is based on the long tradition of Western thought and the division of the world between subject and object; it represents since the times of Aristotle the founding pattern of the classical approach of our society and, consequently, of entrepreneurship research. This refers in Sarasvathy's work to what she designates as causation. On the other hand, the research posture on interaction among individuals of a situation views the dyad as the smallest 
constitutive unit in the sense that Kant understands it. This dyadic approach fits into the idea that men are thinking subjects and that they always integrate the thoughts of others in their own judgment. Fitting into a logic where uncertainty is considered "as a powerful tool in the creation of new ends" (Dew and Sarasvathy, 2002), effectuation appears as the "inverse of causation" (Sarasvathy 2003: 206). If the dyad is the opposite of the monad, then monad and dyad are the two sides of the same coin. In fact, the two postures refer above all to a paradigm of decision in different contexts (Perry, Chandler, Markova, 2011, Schmitt, 2017 et 2020, Schmitt, and Julien, 2020). At the level of causation, it is about making decisions in a certain and rational context. As for effectuation, it refers to the idea of taking decisions in an uncertain context defined as such by Steyaert: "context of uncertainty where neither means nor ends are predetermined" (Steyaert, 2007: 466).

The use of the triad makes it possible to break out of the decision paradigm and go beyond the opposition between causation and effectuation through what is called the entrepreneurial action paradigm. Surprisingly, entrepreneurship research views action as the consequence of decision. However, this is just one of many relationships and other possibilities should be also considered. In fact, action can be a source of decisions or action can lead to other actions (Watzlawick et al., 1967). The complexity of the interaction between decision and action is found in the entrepreneur-artifactnetwork actors triad, where we talk about the entrepreneurial situation. The construction of artifacts in an entrepreneurial situation as the action of the entrepreneur and the network actors leads to decisions being made by one and the other. For instance, an entrepreneur who wants to develop a range of clothes made from sustainable fabrics, will trigger a series of decisions when facing difficulties he may have encountered, when he was led to create a prototype. It is the action that will have triggered decisions.

One could oppose this point of view by saying that behind every action there is a decision. However, although it sounds justifiable as an affirmation, this one fits in the chicken-and-egg paradoxical situation: which is the first to have existed? There is no satisfying answer from the rational point of view. On the other hand, from the perspective of the entrepreneurial action paradigm, all the answers are satisfactory. The term action, taken from the work of Joas (1996), is interesting because it allows to move beyond the decision-action dichotomy and consider the two as interrelated within an entrepreneurial situation. We could even say that the entrepreneurial action paradigm goes beyond action and decision, insofar as it integrates experience (Berglund, 2007) and the intentionality of people in a situation. The entrepreneurial action can be considered in a negentropic way "as the ordering and organization of a world constituted of our experience" (Glasersfled, 1984). These experiences are part of the representation that actors make out of the situation in which they find themselves. The entrepreneurial action paradigm is the translation of the entrepreneur-artifacts-network actors triad and of the communication between these three elements.

If we resume the topic of entrepreneurial intention in the perspective of entrepreneurial action, it would be interesting, beside research dealing with explanations of the object, to be able to develop research studies 
highlighting this time the understanding of the interactions between the entrepreneur and his situated environment and the construction of situated artifacts, in order to examine, for example, actions implemented by a person who intends to undertake entrepreneurial activities, the artifacts developed or the network actors sought by his actions. Research questions emerge, particularly: do the artifacts produced reflect the entrepreneurial intention of the entrepreneur? How do the network actors view the entrepreneurial intention of the entrepreneur through an entrepreneurial situation, that is, his own actions and artifacts? In other words, it is necessary to examine the situated interactions with respect to the entrepreneur-artifacts-network actors triad. Another topic to consider would be that of business opportunity in a triadic perspective. Beyond the fact that the opportunity is a piece of data laccording to the causal perspective) or a construct laccording to the effectual perspective), it is possible to consider opportunity as an artifact by which the relation to the entrepreneur's world, conveyed by his intentionality and his values, reaches the network actors in order to establish communication with them. Conversely, opportunity would also be an artifact that the ecosystem actors will interpret to communicate with the entrepreneur through a situation (Schmitt and Husson, 2017). In the entrepreneurial action paradigm, the artifacts produced by the entrepreneur are signs sent by the entrepreneur to the network actors, referring to the production of other artifacts by the network actors, and so on.

\section{UNDERSTANDING THE TRIAD THROUGH THE ENTREPRENEURIAL ACTION PARADIGM}

The importance of adopting the entrepreneurial action paradigm lies in considering the entrepreneur as a whole (Bygrave and Hofer, 1991) in a situation. Accordingly, the entrepreneur is not defined by himself and should not be viewed as the sole attribute of entrepreneurship. He is defined by a situation through relationships with others (Steyaert, 2007) in a context of interdependence through his artifacts, decisions and actions. The entrepreneurial action paradigm can take the form of communication between the elements of a situation with at least the entrepreneur-artifacts-network actors triad. It is the result of the relation with the world of actors concerned by the situation. This means that there can be no entrepreneurship without entrepreneurs, but also:

- that there is no entrepreneurship without artifacts;

- that there is no entrepreneurship without the network actors;

- that there is no entrepreneurship without communication among the elements of the triad. 
In fact, it is important that the entrepreneur can, very early, communicate his relation to the world through the artifacts and with the network actors. By doing so, the entrepreneur constructs meaning for himself as for others and takes part in the construction of others in relation to entrepreneurial action. The relation to others is an important notion of the entrepreneurial action paradigm. Like any other person, the entrepreneur cannot be separated from himself, nor from his situated action, nor from his network. The result consists in three research propositions in entrepreneurship:

- Proposition 1: It is the artifacts and the network actors that make the entrepreneur exist through an entrepreneurial situation;

- Proposition 2: It is therefore necessary to focus within an entrepreneurial situation on the mediate dimension of entrepreneurship and not be solely limited to the entrepreneur;

- Proposition 3: The meaning does not reside in action; it is introduced by interpretation acts as the entrepreneurial situation evolves.

The entrepreneurial action paradigm seems to be a missing link in the understanding of the entrepreneurial phenomenon. It is situated on the boundaries of communicative action (Habermas, 1985) and creative action (Joas, 1996). It is part of what Venkataraman, Sarasvathy, Dew and Forster (2012) call the development of a new nexus: "new nexus around actions and interactions".

To have a better overview of the elements that represent the entrepreneurial action paradigm, let's summarize them in light of causation and effectuation as follows:

Table 1. Causation, effectuation and entrepreneurial situation: three ways to tackle entrepreneurship (Schmitt, 2020)

\begin{tabular}{|l|l|l|l|}
\hline Logic & Causation & Effectuation & $\begin{array}{l}\text { Entrepreneurial } \\
\text { Situation }\end{array}$ \\
\hline Paradigm & $\begin{array}{l}\text { Paradigm of } \\
\text { decision }\end{array}$ & $\begin{array}{l}\text { Paradigm } \\
\text { of decision }\end{array}$ & $\begin{array}{l}\text { Paradigm of the } \\
\text { entrepreneurial act }\end{array}$ \\
\hline Approach type & Monad & Dyad & Triad \\
\hline $\begin{array}{l}\text { Research } \\
\text { subject }\end{array}$ & Entrepreneur & $\begin{array}{l}\text { 1. Entrepreneur } \\
\text { and artifacts } \\
\text { 2. Entrepreneur } \\
\text { and the ecosystem } \\
\text { actors }\end{array}$ & $\begin{array}{l}\text { Entrepreneur, } \\
\text { artifacts, network } \\
\text { actors }\end{array}$ \\
\hline $\begin{array}{l}\text { Founding } \\
\text { notion }\end{array}$ & $\begin{array}{l}\text { Methodological } \\
\text { individualism }\end{array}$ & $\begin{array}{l}\text { 1. Interactions } \\
\text { 2. Intersubjectivity }\end{array}$ & $\begin{array}{l}\text { Theory of } \\
\text { communication }\end{array}$ \\
\hline Influence & Rationality & Pragmatics & Systemic \\
\hline Origin & Leibniz & Kant & Watzlawick \\
\hline
\end{tabular}




\begin{tabular}{|l|l|l|l|}
\hline Logic & Causation & Effectuation & $\begin{array}{l}\text { Entrepreneurial } \\
\text { Situation }\end{array}$ \\
\hline $\begin{array}{l}\text { Research } \\
\text { elements }\end{array}$ & Object & Interactions & Situations \\
\hline $\begin{array}{l}\text { Research } \\
\text { example }\end{array}$ & $\begin{array}{l}\text { Entrepreneurial } \\
\text { intention }\end{array}$ & $\begin{array}{l}\text { Opportunity } \\
\text { seen as a human } \\
\text { construct }\end{array}$ & $\begin{array}{l}\text { Translation of } \\
\text { intentionality }\end{array}$ \\
\hline
\end{tabular}

\section{DISCUSSION: THE VALUE OF THE} THEORY OF COMMUNICATION AND THE ENTREPRENEURIAL ACTION PARADIGM TO UNDERSTAND ENTREPRENEURSHIP AND TO ENHANCE RESEARCH PERSPECTIVES

At this point of thinking, we have crossed an invisible line that leads us to discuss the importance of extending the scope of studies on effectuation initiated by Sarasvathy. The fact of considering entrepreneurship through the theory of communication has definitely little presence in recent scientific publications. However, this perspective is not only underlying Sarasvathy's work on effectuation in entrepreneurship, but it is starting to make its way in discussions between researchers, in Ph.D. studies for example, and also represent research funding requests. These are weak signals that we stress on through this article. Studies dealing with effectuation are mainly concerned in showing the distinction with the prevailing research in entrepreneurship, aligning itself in an alternative thinking position. As shown by Steyaert (2007), effectuation has two consequences: moving beyond the maximization logic resulting from the classical economic approach (Sarasvathy, 2002) and proposing a humanist vision of entrepreneurship as a philosophy of life ("striving to imagine and create a better world (Sarasvathy et al., 2003: 155). By focusing on the causation/effectuation dichotomy, Sarasvathy will have limited herself to proposing an alternative to the existing one, "the society we want to live in from the society we have to live in" (Sarasvathy 2002: 110). The links between the works on effectuation with pragmatic writers such as James and Dewey, on the construction of meaning such as Weick (1979), or on creative action such as Joas (1996), highlight the will of Sarasvathy to offer a new perspective compared to the rational economic theories, yet without questioning the paradigm of decision (Steyaert, 2007). While the effectual 
approach is interesting and has produced more than a decade of entrepreneurial research, three limitations in Sarasvathy's work can be highlighted:

- Although the artifacts, the entrepreneur and the network actors are present in Sarasvathy's work, they are not considered in a connected way through an entrepreneurial situation;

- The link between artifacts and people in the entrepreneurial situation is weak. However, in a theory of communication, artifacts are part of the communication because they particularly represent the extension of the transmitter (the entrepreneur and the network actors when they are not recipients and they assume in turn the status of transmitters);

- By being limited to the entrepreneur à network actors relationship or entrepreneur à artifacts, Sarasvathy's work explores a single type of relationship. This relationship is part of the decision paradigm. The paradigm of entrepreneurial action invites us to understand entrepreneurial situations more globally.

Through the entrepreneurial action paradigm, we can see that there are different combinations between the elements of the triad, more precisely 6 combinations of interactions at least ${ }^{5}$. The number of interactions of the triad elements increases in a factorial way with the number of entrepreneurs in the project, the number of artifacts developed, and the number of the network actors to be met.

The contribution of phenomenology at this stage is necessary to understand the entrepreneurial situation and therefore the relations between the elements of the triad (Berglund 2015; Schmitt and Husson, 2017). In fact, intention becomes the key issue of the triad. Intentionality in a phenomenological perspective leads us to believe that each individual nurtures his own relationship to the world that he communicates through artifacts, which are a mediated role compared to other individuals in a given situation (Berglund, 2007). This relationship to the world is unconsciously driven by the individual's intent. The actors' intention is communicated through their actions and particularly their artifacts, making it thus conscious. Consequently, there is no entrepreneurship and therefore entrepreneurial situation without the entrepreneur's intention meeting that of the ecosystem actors. The entrepreneur can exist only in relation to the actors of his ecosystem, particularly via the artifacts mobilized in this perspective.

Therefore, the triad is the basic element that enable us to address entrepreneurship. A person is not an entrepreneur because he simply becomes as such. He is an entrepreneur thanks to the convergence of other's intentions. In this perspective, entrepreneurial research clearly sets itself free from the ontological reality and position itself in a constructed reality where

5. Interactions should be considered by using the factoring method. In this case $3 !=3 \times 2 \times 1=6$ 
entrepreneurship would refer to the way in which each one is engaged with himself, with others and with the world. The basic hypothesis denotes the reality perceived by the actors of the entrepreneurial situation, including researchers, and to which the actors of the entrepreneurial situation react. It is not only the result of interactions (the dyad found in effectuation) but also the instruments and language they use to communicate this reality (triad). In other words, everyone constructs a reality which he then translates to others through artifacts. Entrepreneurship becomes thus a translation space, as Latour states (2005), of the intention of various actors and the situated artifacts around the above-mentioned triad. Entrepreneurship thus means the translation of one's intent, one's relationship with the world, with others (Schmitt and Husson, 2017). The translation of such intention is the prerequisite for the stakeholders' commitment as advocated by Sarasvathy (Sarasvathy and Dew, 2005). If we admit from the phenomenological point of view the unconscious nature of the entrepreneur's intent, the challenge of the paradigm of entrepreneurial action becomes to translate, through artifacts, with the network actors, this very part of the unconscious. Artifacts act as traces of the entrepreneur's intention that the researcher must examine. Thus, from a methodological point of view, the posture of the researcher turns into a posture close to that of the ethnologist or the anthropologist looking for traces of human action (Watson, 2013).

From this research direction, various new avenues become available to us. The translation of the entrepreneur's intentionality to the network actors is no easy nor obvious matter (Schmitt and Husson, 2017). Indeed, the translation of this intentionality can lead to discrepancies in the representations of the network actors in relation to the entrepreneur's intentionality conveyed by his artifacts and expressed through his communication. Two avenues seem then interesting to address entrepreneurship in the paradigm of entrepreneurial action: language philosophy and entrepreneur's intentionality. In a theory of communication, language philosophy is important in order to understand the construction of intentionality and the mechanisms of its translation; and logic to particularly identify the formal rules, according to Wittgenstein (Hacker, 1997), in an entrepreneurial argumentation. The second avenue, that we find useful to extend the understanding of entrepreneurship based on the theory of communication, would be that of considering the unconscious of individuals and more particularly of the entrepreneur. In fact, if intentionality is partially unconscious, from the phenomenological point of view, the purpose is to make it conscious through communication. Without being part of a planning, a purpose known in advance in the sense of Suchman (1987), intentionality gives meaning to the entrepreneur's action through his ecosystem. Finally, we believe it is necessary to reconsider important research areas in the field of entrepreneurship, such as entrepreneurial coaching and entrepreneurship training. Indeed, if we consider the importance of the entrepreneurial action paradigm in research, entrepreneurial coaching and entrepreneurship training would move towards new perspectives.

Regarding entrepreneurial coaching, it is necessary to no longer be restricted to technical dimensions such as market research, financing 
plan, etc., and to support the entrepreneur so that he becomes aware of his intentionality and how to translate it to the network actors through the development of artifacts. These artifacts must allow the network actors to see the relationship with the entrepreneur's world. Regarding entrepreneurship training, the same is valid. From the entrepreneurial action perspective, it is important to grant a prominent role to intentionality without being limited to the tip of the iceberg by focusing mainly on easily assessable aspects like the project, market research or financing.

\section{REFERENCES}

Alvarez, S. A., and Barney, J. B. (2007). The entrepreneurial theory of the firm. Journal of Management Studies, 44: p. 1057-1063.

Arend, R. J., Sarooghi, H., and Burkemper, A. (2015). Effectuation as ineffectual? Applying the $3 \mathrm{E}$ theory-assessment framework to a proposed new theory of entrepreneurship. Academy of Management Review, 40(4), p. 630-651.

Berglund, H. (2007). Researching entrepreneurship as lived experience. Dans Neergaard, H. et Ulhøi, J. (dir.), Handbook of Qualitative Research Methods in Entrepreneurship, Cheltenham, Edward Elgar, p. 75-93.

Berglund, H. (2015). Between cognition and discourse: phenomenology and the study of entrepreneurship, International Journal of Entrepreneurial Behavior \& Research, Vol. 21 Issue: 3, p. 472-488

Bygrave, W.D. and Hofer, C.W. (1991). Theorizing about entrepreneurship, Entrepreneurship Theory and Practice, vol. 16, no 2, p. 13-23.

Dew, N. and Sarasvathy, S. (2002). What effectuation is not: further development of an alternative to rational choice, paper presented at the Annual Meeting of the Academy of Management, Denver, C0, 12 August.

Dew, N., Grichnik, D., Mayer-Haug, K., Read, S. and Brinckmann, J. (2015). Situated Entrepreneurial Cognition, International Journal of Management Reviews, 17 : p. 143-164.

Fisher, G. (2012). Effectuation, Causation, and Bricolage: A Behavioral Comparison of Emerging Theories in Entrepreneurship Research, Entrepreneurship Theory and Practice, 36: p. 1019-1051.

Gherardi, S. and Nicolini, D. (2005). Actor-networks: ecology and entrepreneurs, in Czarniawska, B. and Hernes, T. (eds), Actor-Network Theory and Organizing (Copenhagen: Liber \& Copenhagen Business School Press).

Glasersfeld, E. von (1984). An introduction to radical constructivism, in Watzlawick, P. (Ed.) (1984) The invented reality, Norton, New York, p. 17-40.

Habermas, J. (1985). The Theory of Communicative Action. Beacon Press.

Hacker, P.M.S. (1997). Wittgenstein. The great philosophers. Oxford.

Husserl, E. (1913/2017). Ideas: General introduction to pure phenomenology. Martino Fine Book. Joas, H. (1996). The Creativity of Action. Chicago: University of Chicago Press.

Johannisson, B. (1995). Entrepreneurship networking in the Scandinavian context: theoretical and empirical positioning, Entrepreneurship and Regional Development 7 (2), p. 189-192.

Krueger N. and Carsrud A. (1993). Entrepreneurial intentions: Applying the theory of planned behavior. Entrepreneurship \& Regional Development, vol. 5, n4, p. 315-330. 
Krueger, N. (2017). Is Research on Entrepreneurial Intentions Growing? Or...Just Getting Bigger?, In: Malin Brännback, Alan L. Carsrud, dir., Revisiting the Entrepreneurial Mind. Inside the Black Box: An Expanded Edition, Heidelberg: Springer, p. 35-40.

Latour, B. (2005). Reassembling the Social, An Introduction to Actor-Network Theory, Oxford: Oxford University Press.

Moroz, P. W. and Hindle, K. (2012). Entrepreneurship as a process: toward harmonizing multiple perspectives, Entrepreneurship Theory and Practice, July, p. 781-818.

Perry, J. T., Chandler, G. N. and Markova, G. (2011). Entrepreneurial effectuation: a review and suggestions for future research, Entrepreneurship Theory and Practice, July, p. 837-861.

Read, S., Sarasvathy, S., Dew, N. and Wiltbank, R. (2016). Response to Arend, Sarooghi, and Burkemper (2015): Cocreating Effectual Entrepreneurship Research. Academy of Management Review, July; 41(3): p. 528-536.

Reymen, I. M. M. J., Andries, P., Berends, H., Mauer, R., Stephan, U. and van Burg, E. (2015). Understanding Dynamics of Strategic Decision Making in Venture Creation: A Process Study of Effectuation and Causation ? Strategic Entrepreneurship Journal, 9: p. 351-379.

Sarasvathy, S. (2001). Causation and effectuation: toward a theoretical shift from economic inevitability to entrepreneurial contingency, Academy of Management Review, 26: p. 243-263.

Sarasvathy, S. (2002). Entrepreneurship as economics with imagination, Ruffin Series in Business Ethics, 3: p. 95-112.

Sarasvathy, S. (2003). Entrepreneurship as a science of the artificial. Journal of Economic Psychology, 24 (2003) p. 203-220.

Sarasvathy, S. and Dew, N. (2004). When Markets are Grue. Darden Business School Working Paper, No. 04-06, June.

Sarasvathy, S. and Dew, N. (2005). New market creation through transformation. Journal of Evolutionary Economics, vol. 15. n5, p. 533-565.

Sarasvathy, S., Dew, N., Read S. and Wiltbank, R. (2008). Designing organizations that design environments: Lessons from entrepreneurial expertise, Organization Studies, Vol 29, Issue 3, p. 331-350.

Sarasvathy, S. and Venkataraman, S. (2011). Entrepreneurship as method: open questions for an entrepreneurial future. Entrepreneurship Theory and Practice, Volume: 35 issue: 1, p. 113135.

Sarasvathy, S., Kumar, K., York, J. G. and Bhagavatula, S. (2014). An Effectual Approach to International Entrepreneurship: Overlaps, Challenges, and Provocative Possibilities. Entrepreneurship Theory and Practice, 38: p. 71-93.

Schmitt, C. (2020). Nouvelles perspectives en entrepreneuriat, Vuibert.

Schmitt, C., Julien, P. (2020). Causation, effectuation, improvisation et agir entrepreneurial. Pour une approche renouvelée et intégrative de l'entrepreneuriat. Projectics / Proyéctica / Projectique, 25(1), p. 131-153.

Schmitt, C. (2018). La fabrique de l'entrepreneuriat. Dunod.

Schmitt, C. and Husson, J. (2017). Entrepreneurial situations, definition and interests for entrepreneurial research, International Journal of Entrepreneurship and Small Business, Vol.30, No.1, p. 22-37.

Schmitt, C. (2017). Quel paradigme pour la recherche en entrepreneuriat : Du paradigme de la décision au paradigme de l'agir entrepreneurial. Gestion 2000, volume 34(5), p. 249-256

Schmitt, C. (2015). La place de l'action dans la recherche en entrepreneuriat : pour le développement d'un agir entrepreneurial. Projectics / Proyéctica /Projectique, 15(3), p. 113-128.

Schmitt, C. (2015). L'agir entrepreneurial. Repenser l'action des entrepreneurs. Presses de l'Université du Québec.

Smolka, K. M., Verheul, I., Burmeister-Lamp, K. and Heugens, P. P. (2016). Get It Together! Synergistic Effects of Causal and Effectual Decision-Making Logics on Venture Performance, Entrepreneurship Theory and Practice. doi:10.1111/etap.12266 
Steyaert, C. (2007). 'Entrepreneuring' as a conceptual attractor? A review of process theories in 20 years of entrepreneurship studies, Entrepreneurship and Regional Development, 19, November, p. 453-477.

Steyaert, C. and Landström, H. (2011). Enacting entrepreneurship research in a pioneering, provocative and participative way: On the work of Bengt Johannisson, Small Business Economics, 36(2), p. 123-134.

Suchman, L.A. (1987). Plans and situated actions: The problem of human-machine communications, Cambridge, UK.

Townsend, D. Hunt, R., McMullen, J. and Sarasvathy, S. (2018). Uncertainty, Knowledge Problems, and Entrepreneurial Action. Academy of Management Annals. 10.5465/ annals.2016.0109.

Venkataraman, S., Sarasvathy, S., Dew, N. and Forster, W. (2012). Reflections on the 2010 AMR Decade Award: whither the promise? Moving forward with entrepreneurship as a science of the artificial, Academy of Management Review, 37, 1, p. 21-33.

Watson, T. J. (2013), Entrepreneurship in action: bringing together the individual, organizational and institutional dimensions of entrepreneurial action, Entrepreneurship and Regional Development, vol25, n5-6, p. 402-422.

Watzalawick, P., Helmick Beavin, J. and Jackson, D. D. (1967). Pragmatics of human communication: a study of interactional patterns, pathologies and paradoxes, W.W. Norton \& Co., New-York.

Weick, K. (1979). The Social Psychology of Organizing (Reading, MA: Addison-Wesley).

Welter, F. (2011). Contextualizing entrepreneurship, conceptual challenges and ways forward, Entrepreneurship Theory and Practice, January, p. 165-184.

Christophe Schmitt est Vice-Président de l'Université de Lorraine. Il est Professeur des Universités à l'IAE de Metz (France). Il y est Titulaire de la Chaire «Entreprendre » et responsable du Pôle entrepreneuriat étudiant de Lorraine (PeeL). Il est également Professeur associé à la Louvain School of Management (Belgique) et à la Haute Ecole de Gestion de Fribourg (Suisse). Ses articles et ouvrages portent sur le développement d'une théorie de l'action entrepreneuriale. Son dernier ouvrage s'intitule « Nouvelles perspectives en entrepreneuriat. Du modèle du télégraphe au modèle de l'orchestre ».

\section{ANNEX}

\begin{tabular}{|l|l|l|l|}
\hline References & Intersubjectivity & Artifact & Communication \\
\hline Sarasvathy, S. 2001 & 0 & 2 & 0 \\
\hline Sarasvathy, S. 2002 & 0 & 8 & 0 \\
\hline Sarasvathy, S. 2003 & & 20 & 0 \\
\hline Sarasvathy, S. and Dew, N. 2004 & 2 & 29 & 2 \\
\hline Sarasvathy, S., and Dew, N. 2005 & 0 & 27 & 0 \\
\hline $\begin{array}{l}\text { Sarasvathy, S., Dew, N., Read S. } \\
\text { and Wiltbank, R. 2008 }\end{array}$ & 1 & 29 & 0 \\
\hline
\end{tabular}




\begin{tabular}{|l|l|l|l|}
\hline References & Intersubjectivity & Artifact & Communication \\
\hline $\begin{array}{l}\text { Sarasvathy, S. and Venkatara- } \\
\text { man, S. 2011 }\end{array}$ & 2 & 3 & 0 \\
\hline $\begin{array}{l}\text { Venkataraman, S., Sarasvathy, } \\
\text { S., Dew, N., and Forster, W. 2012 }\end{array}$ & 18 & 12 & 0 \\
\hline $\begin{array}{l}\text { Sarasvathy, S., Kumar, K., York, } \\
\text { J. G. and Bhagavatula, S. 2014 }\end{array}$ & 11 & 3 & 1 \\
\hline $\begin{array}{l}\text { Towsend, D, Hunt, R., Mc Mullen } \\
\text { J, Sarasvathy, S. 2018 }\end{array}$ & 11 & 4 & 0 \\
\hline
\end{tabular}

Legend. Semantic analysis of Sarasvathy's work 